\title{
In the Original Greek
}

\author{
By G. G. Neal
}

A CLASSICIST WRITING to theologians about the Greek of the New Testament will be greeted with a pitying smile. Greek to him is the sophisticated, literary language used in Athens 500 years before Christ, a far cry from the straightforward colloquialism of ordinary people refiected in the apostolic writings. It is only to be expected that he will read non-existent subtleties into New Testament grammar, treat the etymology anachronistically, and in short assume a Peter to have possessed knowledge as abstruse as Sophocles. He will cut a pathetic figure, just as Dr. Johnson would if he were to come to life and castigate the spelling of an advertisement for milk.

The purpose of this article is to turn exactly this charge against the theologians. It is they who murder language. Too often they treat their 'straightforward' koine with a rigour which no classicist would apply even to his 'sophisticated' Attic. Preachers and commentators offend most, and so I want to draw attention to some linguistic methods of exegesis in common use which are of doubtful validity or of doubtful relevance.

\section{Present and Aorist}

A deeply ingrained theory is the supposed distinction between the present and aorist tenses of the Greek verb in the infinitive, imperative, and subjunctive. The duplication of these forms seems redundant to an English speaker, but an explanation is given that the present has a continuous or frequentative reference, while the aorist applies to instantaneous or particular actions. (Notice that the distinction itself is not unambiguous.) This rule appears in all the grammars, (see, for example, Moule, Idiom-book of New Testament Greek, p. I35; Blass-Debrunner, ${ }^{11}$ p. 206)

It is invoked extensively in practice. On page II 35 of The New Bible Commentary we read this comment on I Peter 2:13: 'Peter seems to prefer the aorist imperative to the present in commands, pointing rather to the definite decision to submit than to the continual act of submission.' From this it is easy to imagine the frequent appeals made to a convenient aorist to prove that sanctification is a matter of crisis and surrender, or to a convenient present tense to prove the opposite view. One party cites Romans I2:I; the others concentrate on Romans I $2: 2$ ! 
Unfortunately, the distinction is a debated one. Grammarians usually state it dogmatically, but they are concerned to produce clear-cut rules. Professor Moule, however, does admit that usage is fluid, and cites several examples that defy the principle. His list could be extended indefinitely. Notice the inexplicable variation of I Peter 2:1 7, - which The New Bible Commentary does not mention! 'Honour (aorist) all men. Love (present) the brotherhood. Fear (present) God. Honour (present) the king.' In John 15:16 the first subordinate clause contains 3 present subjunctives, the second 2 aorists. One more instance will suffice: why does John 7:24 use first the present and then the aorist of the same verb?

There are many factors which might have led a Greek writer to choose one or other tense of these moods of the verb. Certainly one of them might have been the analogy of the imperfect and aorist tenses of the indicative, which are differentiated in this way. But considerations of euphony, the predominant tense of the passage, differences in style, and other criteria could have had equal weight. To a great extent also I suspect the choice is arbitrary. This means that while it may be interesting to speculate on what led Paul to use the present tense in Ephesians 5:18 for instance, it is not firm enough foundation to support an attack on the doctrine of the second blessing. And in most cases, as it is misleading to use this grammatical point as evidence for a theory, so it is irrelevant to mention it at all.

\section{Questions of Vocabulary}

We must beware of rigid distinctions in vocabulary too. The occurrence of $2 \lambda \lambda 0_{0}$ in John 14:16 is sometimes adduced as proof of the divinity of the Holy Spirit. It is alleged that Greek had two words for 'another', ¿' $\lambda \lambda \mathrm{S}_{5}$ meaning 'another of the same kind' and

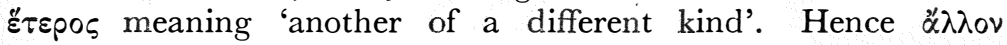
$\pi \alpha \rho \alpha \dot{x \lambda \eta \eta \tau o v ~ i n d i c a t e s ~ a ~ P a r a c l e t e ~ d i v i n e ~ l i k e ~ C h r i s t . ~}$

Some support for this argument is found in Galatians $1: 6,7$, where Paul's use of both words seems to imply some distinction between them. But this parallel falls down the moment we try to work out the exact shades of meaning. It is merely a question of style. Paul varies his vocabulary for effect, where in English we should have preferred to keep the same word for effect, as the Authorised Version does.

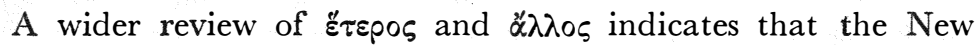
Testament writers used them as synonyms. Matthew 27:42 uses

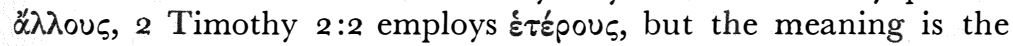
same. And it would be splitting hairs to differentiate between the 
words in I Corinthians i $2: 8$-1 o, or 2 Corinthians I I :4. Use every valid argument to prove the divinity of the Holy Spirit, but not the Greek of John 14:16; it means as much or as little as the English.

(Incidentally, Jehovah's Witnesses appeal to the Greek to belittle the Holy Spirit, but they too are mistaken. The answer to their claim that $\pi v \varepsilon \tilde{\mu} \mu \alpha$ is a neuter noun and hence refers to an influence, not a person, is simple. $\pi \alpha$ idiov is also a neuter noun, but that does not depersonalise children! And why is a masculine pronoun frequently used with $\pi v \varepsilon \tilde{u} \mu \alpha$, as in John $r 6: 13$ ?)

When we think of the varied senses of a common English verb like 'see', it is incredible that anyone should attribute rigid and subtle distinctions to the Greek words ópó $\omega$ and $\theta \varepsilon \omega p \varepsilon ́ \omega$. But consider this statement, made by Frank W. Moyle (Our Undying Self, Longmans Green, I958), and quoted with approval by Dr. L. D. Weatherhead (The Resurrection of Christ, Hodder \& Stoughton I959, p.50). 'If this (John $16: 16$ ) had received the attention which the writer of the Fourth Gospel obviously intended it to receive, there would have been less controversy about the nature of Christ's Resurrection. I have no doubt that he intended by using the word "behold" (theoreo) for Jesus's physical presence, and "see" (horao) for His spiritual or resurrection presence, to rule out the idea (so deeply imbedded in the Jewish mind) of a physical or bodily resurrection.'

Needless to say, it is not true that $\theta \varepsilon \omega p \varepsilon \omega$ is confined to physical perception: John 4:19 clearly refers to mental insight. Nor is it true that óp $\alpha \omega$ is never used of the physical: what of John 9:37, 20:25? The reason why the two verbs appear side by side in John $16: 16$ is that the future tense of $\theta \varepsilon \omega \rho \varepsilon \omega$ does not occur in the New Testament, and is replaced, so synonymous are the words, by the future of ópów.

\section{Misuse of the Dictionary}

Two other devices in the realm of vocabulary have to be used with great caution. One is the argument from etymology. Take,

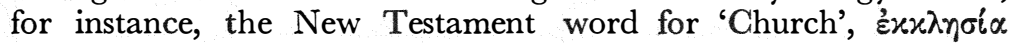
This word comes from two roots meaning 'call' and 'out:' it might therefore be asserted on this basis that the Church is the called-out community of believers. The doctrine is true, but is the reasoning valid? One can talk about 'provoking' a dog in his kennel, but the choice of the verb there is not determined by its original meaning 'to call forth'. The fact that a word's history is edifying does not make it relevant. The only thing we will be concerned with in exposition is its meaning in the particular context. Sometimes etymology will explain that, sometimes not. 
The case of $2 x x \lambda \eta \sigma^{\prime} \alpha$ illustrates another dangerous stratagem, the argument from parallel uses of the same word. For it was a political term, the name given to the sovereign assembly of citizens in a democratic state. Applied to the Church, this would convey a totally different truth. But again we must in all honesty ask whether this parallel is relevant to the New Testament connotation of the word, before deducing any lesson from it.

Both of these interpretations appear inadequate, when we con-

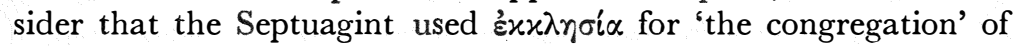
Israel: see Deuteronomy $31: 30$, etc.; cf. Acts 7:38. The New Testament writers surely used it of the body of Christ because they were familiar with it in this sense. Whatever prompted the translators of the Greek Old Testament to adopt it, their reasons would have been forgotten as the word gathered round it the associations of its new context. The apostles, brought up in the Jewish tradition, would have been oblivious of its political or etymological background.

But so imprecise a medium of communication is language, that to the early Greek converts $\varepsilon x x \lambda \eta \sigma^{\prime} \alpha$ may well have retained its political connotations when they first heard it on Paul's lips. How could it have been otherwise in Ephesus, for instance, where the same name was given even to the stormy meeting in the theatre recorded in Acts 19:32? Speculation is dangerous, but it would help to explain the anarchy and confusion at Corinth, if the Christians had got the impression that a Church service was something of a political meeting!

\section{Equivocation}

Reading two possible meanings into a text simultaneously is a good way to display a knowledge of Greek. How many preachers have expounded Galatians 2:20 like this? Having made the point that the driving force of Paul's life was faith in Christ, they proceed to explain that $\pi i \sigma \tau i \zeta$ can also mean faithfulness, and suggest that Paul was also alluding to the assurance he drew from Christ's steadfast love. Two lessons for the price of one.

But language does not work like this. Words, except perhaps in the most modern poetry, cannot bear two different meanings at the same time. In the instance I have mentioned, either translation is theoretically possible, although the word order strongly suggests the first. But it is unrealistic and thoroughly confusing to combine the two.

I notice with some trepidation that Dr. E. M. Blaiklock, himself Professor of Classics at Auckland University, did something similar in his comments on Acts 13:48 in the Scripture Union notes. He 
wrote: "The words "were ordained" in verse 48 are translated from a verb which is in a mood which includes personal action, and has in it the idea "as many as had ranged themselves for eternal life." The Jews had "judged themselves" (46) unworthy, and eager Gentiles were putting themselves into their place, "getting into line", if the military content of the metaphor is to be stressed. I: is not only a matter of sovereign selection by God, although this concept underlies the verse.' Professor Blaiklock is no doubt right to point out the fact of human responsibility as well as divine election in salvation, but it would seem that his desire to do this had led him to read a gratuitous implication into the words 'were ordained'. Far be it from me to deny that the Greek words could be in the middle voice and mean 'had got into line'. But if that is their meaning here, there is no reference to 'sovereign selection', which would represent the passive. Now Professor Blaiklock admits that that concept does underlie the verse, and the pluperfect tense, as well as the vast preponderance of usage of the verb, makes it virtually certain that the Authorised Version is correct. But in that case, it violates commonsense to see any sign of personal action in the words; the two aspects are much further apart than the two meanings of $\pi i \sigma \tau \iota \varsigma$.

\section{Positive Value of Greek}

In spite of these destructive criticisms, I believe as firmly as anyone that it is impossible to interpret the New Testament for oneself without a knowledge of Greek. This alone can guard against misunderstanding due to the gradual changes in the English language, the inadequacies of translators, and ambiguities in the rendering. I aim to deter no one from studying the language, but rather to give encouragement to learn it more thoroughly. Too little knowledge or second-hand knowledge is usually to blame for the practices I have criticised.

Nor am I opposing all mention of Greek in sermons and commentaries. But it should be kept to a minimum to avoid unnecessarily confusing and disheartening those who know none. Often a point can be supported adequately from the English, and there is no reason to parade our lexicons. My main target, however, is the tragic prevalence of linguistic arguments which are based on precarious or false assumptions about the meaning of what is written in the original Greek. 